$1-1-1933$

\title{
The Bacterial Flora of High-Grade Milk Before and After Pasteurization
}

\author{
L. M. Thurston
}

H. C. Olson

Follow this and additional works at: https://researchrepository.wvu.edu/ wv_agricultural_and_forestry_experiment_station_bulletins

\section{Digital Commons Citation}

Thurston, L. M. and Olson, H. C., "The Bacterial Flora of High-Grade Milk Before and After Pasteurization" (1933). West Virginia Agricultural and Forestry Experiment Station Bulletins. 255.

https://researchrepository.wvu.edu/wv_agricultural_and_forestry_experiment_station_bulletins/256 @ WVU. It has been accepted for inclusion in West Virginia Agricultural and Forestry Experiment Station Bulletins by an authorized administrator of The Research Repository @ WVU. For more information, please contact ian.harmon@mail.wvu.edu. 
West Virginia University Libraries

| || |-

...

308021005210310 
Digitized by the Internet Archive in 2010 with funding from

Lyrasis Members and Sloan Foundation 


\title{
The Bacterial Flora of High-grade Milk Before and After Pasteurization
}

\author{
BY L. M. THURSTON AND H. C. OLSON
}




\section{Agricultural Experiment Station StafF}

JOHN R. TURNER, Ph. D., LL. D., President of the University F. D. FROMME, Ph. D. ................. Dean and Director GERALD JENNY, M. S., Agricultural Editor .... JOIHN C. JOHNSTON, Chief Clerk

\section{AGRONOMY AND GENETICS}

R. J. Garber, Ph. D.

Agronomist and Geneticist

W. H. Pierre, Ph. D.

Associate Agronomist

M. M. Hoover, Ph. D.

Associate Agronomist

T. C. McIlvaine, Ph. D.* Assistant Agronomist

G. G. Pohlman, Ph. D. Assistant Agronomist

H. K. Rowley, M. S. Agr.** Seed Analyst

\section{ANIMAI, HUSBANDRY}

E. A. Livesay, D. Sc. Animal Husbandman

C. V. Wilson, M. S. Assistant Animal Husbandman

J. H. Longwell, M. A. Assistant Animal Husbandman

R. H. Tuckwiller, B. S. Agr.* Assistant Animal Husbandman

J. H. Rietz, D. V. M.** Associate Veterinarian

E. N. Moore. D. V. M** Assistant Veterinarian

\section{CHEMISTRY}

R. B. Dustman, Ph. D. Agricultural Chemist

C. E. Weakley, Jr., M. A. Assistant Chemist

T. B. Leith, M. S.** Assistant Chemist

I. J. Duncan, M. S. Assistant

A. H. Van Landingham, M. S. Assistant

\section{DAIRY HUSBANDRY}

H. O. Henderson, $\mathbf{P h}$. D. Dairy Husbanaman

L. M. Thurston, $\mathrm{Ph}, \mathrm{D}$. Associate Dairy Husbandınan

G. A. Bowling, M. S. Assistant Dairy Husbandman

R. A. Ackerman, M. S. $\ddagger$ Assistant Dairy Husbandman

\section{ENTOMOLOGY}

I. M. Peairs, Ph. D. Entomologist

W. E. Rumsey, B. S.** State Entomologist

Edwin Gould, B. S. Agr. Assistant

FARM ECONOMICS

A. J. Dadisman, Ph. D. Farm Econonist

W. W. Armentrout, Ph. D. Associate Farm Economist

F. D. Cornell, Jr., M. S. Assistant Farm Mechanician

R. O. Stelzer, M. S. Assistant

HOME ECONOMICS

Rachel H. Colwell, M. A. Home Economist

Hazel C. Cameron, M. A. Research Specialist in Nutrition HORTICULTURE

H. E. Knowlton, Ph. D. Horticulturist

K. C. Westover, M. S. Assistant Horticulturist

Leif Verner, M. S. Assistant Horticulturist

E. N. McCubbin, M. A. Assistant

A. P. Dye, M. S. Agr. Assistant

W. H. Childs, M. S. Assistant

PLANT PATHOLOGY

C. R. Orton, Ph. D. Plant Pathologist

Anthony Berg, M. S. Associate Plant Pathologist

L. H. Leonian, Ph. D. Associate Plant Pathologist

F. J. Schneiderhan, Ph. D. $\dagger^{\dagger}$ Associate Plant Pathologist

\section{POULTRY HUSBANDRY}

T. B. Clarlk, M. S. Assistant

E. T. Wightman, M. S. Assistant

*In cooperation with the U. S. Department of Agriculture, Washington, D. C.

* In cooperation with the State Department of Agriculture, Charleston, W. Va.

tIn charge of the Lakin Experiment Farm, Lakin. W. Va.

$\ddagger$ In charge of the Reymann Memorial Farms, Wardensville, W. Va.

†† In charge of the University Experiment Farm, Kearneysville, W. Va. 


\title{
The Bacterial Flora of High-Grade Milk Before and After Pasteurization*
}

\author{
by L. M. THURSTON and H. C. OLSON
}

PART I. Percentage Revection of Bicterlal Count bi Pasteurization, And Proportions of Physiologic AND

Morphologic Types Present

T THE PAST much of the high-grade milk has been sold rav, 1 and little is known of the effect of pasteurization on the flora of such milk. Ayres and Johnson (2) in studying relatively high-count milks determined the proportions of physiologic types of bacteria in pasteurized milk as compared with those found in the raw milks. These investigators divided the types into four groups: i. e., acidforming, inert, alkali-forming, and peptonizing, as shown on plates of litmus-lactose-agar and litmus-lactose-gelatin. They found that in raw milk the inert group was largest, followed in order by the acid-forming, peptonizing, and alkali-forming groups. Pasteurization at $145^{\circ} \mathrm{F}$. $\left(62.8^{\circ} \mathrm{C}\right.$.) resulted in an increase in the proportion of acid-forming bacteria and in decreases in the alkali-forming, peptonizing, and inert groups. At pasteurizing temperatures above $170^{\circ} \mathrm{F} .\left(76.7^{\circ} \mathrm{C}\right.$.) the acid group was largely destroyed and the relative proportion of peptonizing organisms greatly increased. They found only a small percentage of spore-forming bacteria in milk pasteurized at $145^{\circ} \mathrm{F}$. for 30 minutes.

Later, Ayres and Johnson (3) found that by inoculating tubes of sterile litmus milk, each with a single colony grown on a plate, and incubating these tubes for 14 days at $30^{\circ} \mathrm{C}$., they could divide the types of bacteria into their respective groups more accurately than by the use of litmus-lactose-gelatin or -agar. By this method they also distinguished two types of acid-producing bacteria: $i$. e., acid-forming and acid-coagulating. This method was found to show a higher percentage of acid-producing and peptonizing and fewer inert and alkali-producing bacteria than was shown on litmus-lactoseagar and litmus-lactose-gelatin. They studied three grades of raw milk, the best including 12 samples with an average count of 24,700 , the second, 24 samples with an average count of $3,451,000$, and the

* A portion of the data presented in this bulletin was included in a thesis submitted by Mr. Olson in partial fulfilment of the requirements for the degree of Master of Science. 
poorest, 20 samples with an average count of 32,950,000. Comparisons were made with the types grown on beef-infusion-agar and casein-agar. In general the infusion-agar gave a higher percentage of acid-coagulating bacteria and a lower percentage of alkali-forming and peptonizing bacteria than the casein agar.

Black, Prouty, and Graham (r) studied 20 samples of low-count milk before and after pasteurization in flasks. Differentiation of types of colonies was made by plating on Bacto-nutrient-caseinateagar to which brom cresol purple was added previous to sterilization. Color changes of the medium around the colonies indicated the production of acid or alkali, and proteolytic types were recognized by a clear halo around the colony when the plate was flooded with dilute acetic acid. The average count of the raw milks was 3,467 and that of the pasteurized milks, 374. The distribution of types of bacteria in the raw milk when fresh was: acid-forming, 26.17 percent; proteolytic, 0.76 percent; and inert and alkali-forming, 73.07 percent. In the pasteurized milks the distribution was: acid-forming, 14.64 percent; proteolytic, 0.62 percent; and inert and alkali-forming, 84.74 percent. They found that the reduction in bacterial count due to pasteurization ranged from 61.3 to 99.95 percent, with an average reduction of 89.1 percent.

According to Harding, Ward, and Harding (10), early studies showed that during pasteurization there was a greater reduction in the proportion of the non-acid-forming bacteria than in the other forms; consequently a higher percentage of acid-forming bacteria was found in the milk after pasteurization than before.

Many studies have been made of the bacteria that survive pasteurization. Rogers (20) and Maze (14) found strains of lactic-acid bacteria which were able to withstand $168^{\circ} \mathrm{F}$. $\left(75.6^{\circ} \mathrm{C}\right.$.) during a 30 minute holding period. Prickett (16) isolated 480 cultures of thermophilic and thermoduric organisms from milk. Tanner and Harding (23) reported that thermophiles are nearly always present in raw milk. Hammer and Trout (9) and Hucker (12) described a large number of cocci which are able to survive pasteurization, and Robertson (17) has identified a number of non-sporeforming thermophilic and thermoduric bacteria found in pasteurized milk. Tanner and Windsor (24), Beavens (6), and Ayres and Johnson (3) found considerable variation in the ability of Escherichia coli to survive pasteurization, but they agree that in the majority of the cases the thermal death point is below $145^{\circ} \mathrm{F}$. $\left(62.8^{\circ} \mathrm{C}\right.$.) for 30 mintites and that survival is due to a few highly-resistant cells. Several types of alkali-forming bacteria studied by Ayres, Rupp, and Johnson (5) were found to have thermal death points varying from $140^{\circ} \mathrm{F} .\left(60^{\circ} \mathrm{C}\right.$.) to $150^{\circ} \mathrm{F}$. $\left(65.6^{\circ} \mathrm{C}\right.$.) for 30 minutes.

Robertson (18) on reviewing the literature concluded that the ability of living protoplasm to survive high temperatures depends in part on its low moisture content. He (19) then showed that the 
young, growing bacteria are more susceptible to heat than older cells. Sherman, Stark, and Stark (22) also have shown that the age of bacterial cells is an important factor relating to efficiency of destruction of organisms by pasteurization.

Husong and Hammer (13) in studying pasteurization efficiencies obtained with milks from individual farms, when pasteurization was at $142^{\circ} \mathrm{F}$. $\left(61.1^{\circ} \mathrm{C}\right.$.) in test tubes, found a wide variation in the percentages of bacteria destroyed. No close relationship was found between the initial counts and pasteurization efficiencies. These workers observed that low counts of pasteurized milk occurred more frequently when the milk was produced and handled so that it had low initial counts than when it had high initial counts.

\section{EXPERIMENTAL WORK}

The milk used in this work was produced at the Dairy farm of the West Virginia Agricultural Experiment Station and processed in the Station creamery. Most of the milk was machine-drawn. Conditions were controlled so that the milk usually yielded a standard plate count lower than 10,000 bacteria per cubic centimeter when delivered to the creamery.

The pasteurizer used in this work was of the kettle type, glasslined, equipped with heating jacket, rotating-paddle agitator, and both recording and indicating thermometers. Its capacity was 150 gallons.

Immediately after the milk was received it was placed in the pasteurizer, mixed, and a sample taken by means of a sterile glass tube. This sample was placed in a sterile screw-capped tube and held in a refrigerator at $38^{\circ} \mathrm{F}$. $\left(3.3^{\circ} \mathrm{C}\right.$. $)$. The milk was carefully pasteurized at $145^{\circ} \mathrm{F} . \pm 0.5^{\circ}\left(62.8^{\circ} \mathrm{C}\right.$.) for 30 minutes. At the end of the holding period another sample was taken in the same manner as the first and placed on ice to cool. The milk was next pumped over the covered surface cooler and into the covered tank of the bottler. Finally a machine-filled bottle was taken for examination as near midway through the bottling procedure as possible. The samples of raw and pasteurized milk were used in the determinations of bacterial reduction by pasteurization and of morphologic types present, and all three samples were used in the study of physiologic types of bacteria present before and after pasteurization.

Immediately after pasteurization, cooling, and bottling was completed, the pasteurizer was rinsed with warm water, washed by means of washing powder and brush, rinsed, and steamed while closed until a temperature of $180^{\circ} \mathrm{F}$. or higher was reached. The pipelines, pump, and bottling machine were taken apart completely and washed, rinsed, and all pipes steamed. The pump and bottler were steamed after being reassembled. The cooler was washed and rinsed and then thoroughly steamed with the covers in place forming a chamber around it. Just before the next use of the equipment the pipe lines were assembled and "sterilized" by either hot water or 
chlorine rinse. Hot water "sterilization" consisted of placing about 50 gallons of water at $180^{\circ} \mathrm{F}$. or higher in the pasteurizer, brushing the water over the sides above the water level by means of a clean brush, and then pumping the water through the entire system, allowing it to run freely through the bottling machine tank. Chlorine "sterilization" consisted of placing about 30 gallons of warm water in the pasteurizer, adding enough stock solution of active chlorine to yield 60 parts per million (p. p. m.) of available chlorine after passing through the system, and brushing the solution over the sides of the pasteurizer that were not submerged with a clean brush before pumping.

\section{Reduction of Bacterial Count by Pasteurization}

Two studies of bacterial reduction by pasteurization were conducted. The first trial included counts of the raw and pasteurized milks of 103 deliveries, made, for the most part, on successive days. During this trial the vat was washed and steamed immediately after each use, then rinsed with hot water at about $180^{\circ} \mathrm{F}$. $\left(83^{\circ} \mathrm{C}\right.$.) just before receiving the milk on the following morning. Bacterial counts were made according to Standard Methods of Milk Analysis (1), except that the agar used contained one percent of lactose. Counting was done under illumination with the aid of a hand lens and counting card.

The data collected in this study are summarized in Table 1. Percentage reduction of bacterial counts by pasteurization was found to increase as the counts of raw milk increased. Pasteurization of the raw milks showing counts below 5000 resulted in an average reduction in count of 75.39 percent as compared with 99.37 percent for milks with counts higher than 60.000 before pasteurization. Change in percentage destruction as related to the counts of the raw milk are shown by graph in Figure 1.

The data also show that the percentage reduction in count due to pasteurization was more variable in low-count raw milks than in higher-count milks. Standard deviations and coefficients of variability of the percentage reduction in counts for each group which are given in Table 1 show a wide variability for the low-count group, decreasing progressively with increases of the raw-milk count. These changes also are shown in Figure 1 . It is of interest to note that a reasonably constant number of bacteria survived pasteurization irrespective of the count of the raw milk, as shown in Table 1.

The second trial included counts of the raw and pasteurized milks of 74 deliveries, made, for the most part, on successive days. Counts were made by the same method as in the first trial except that lactose was not used in the media, but Standard Methods (1) were followed exactly. As no appreciable differences were noted in a number of comparisons between lactose agar and standard agar, 


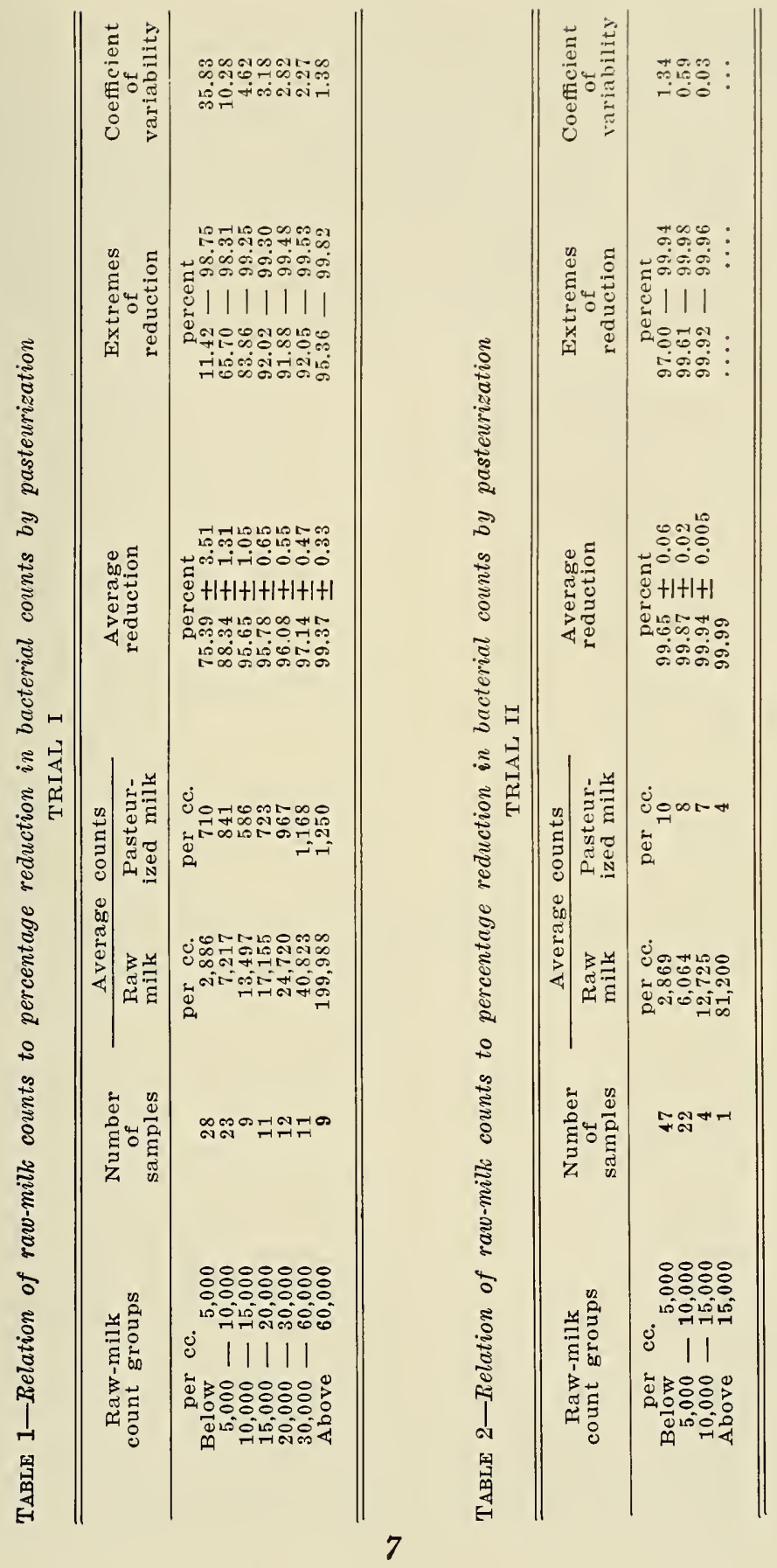


it was felt that the use of the two media did not introduce an error of any magnitude when comparing results of the two trials.

This trial was begun more than a year after the first was completed. Sometime after the first trial was completed the shaft of the pasteurizer agitator was found to be in a bad condition and leaky, and was repaired. During a three-month period of the intervening time the vat was given a chlorine rinse each morning just before receiving the milk. For a period of one month before starting the second trial no chlorine was used. At the beginning of this trial, however, the use of chlorine was resumed. During the trial the use of chlorine was omitted for a period of two weeks, but no variation in results occurred.

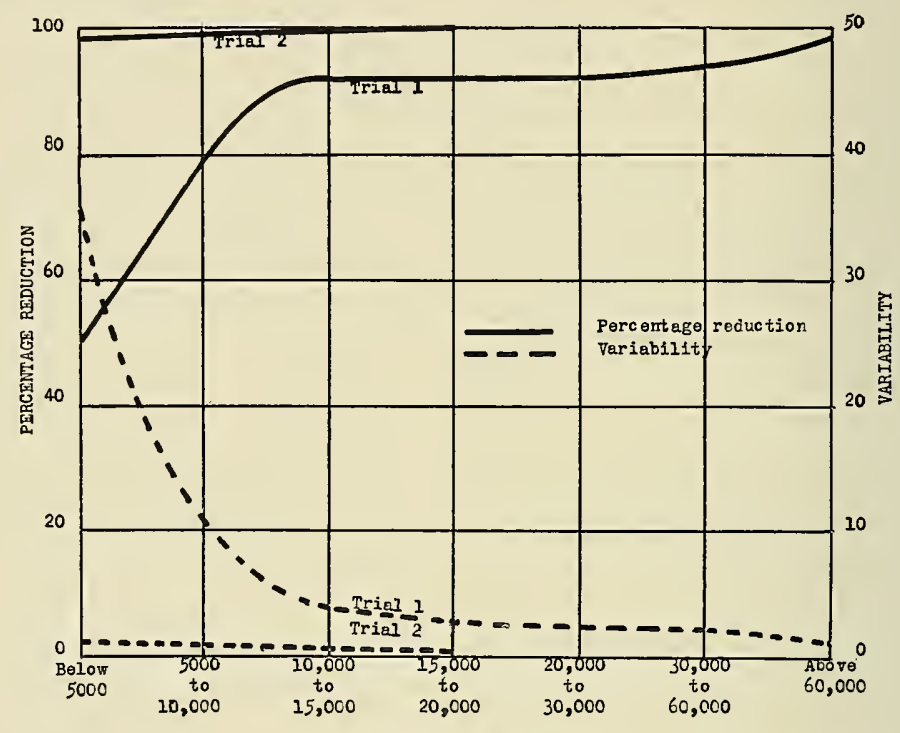

RAW-MILX COUNT GROUPS

FIG. 1-A comparison of the percentage reduction of bacterial counts due to pasteurization and of the variability of percentage destruction

The results of this study are summarized in Table 2. Percentage reduction of bacterial count by pasteurization was found to increase as the counts of the raw milk increased, but decreases were so slight as to be of little significance. The outstanding difference between results of this trial and those of the previous one lies in the counts of the pasteurized milks. The average bacterial count of the pasteurized milks in trial 1 was 856 per cubic centimeter, whereas in trial 2 it was 9 per cubic centimeter. As a result the percentage reduction in count in the second trial was greater and less variable than in the first. Nevertheless, general tendencies were in the same direction: i. e., percentage reduction in count due to pasteurization increased as the counts of the raw milk increased, and percentage re8. 
duction was more variable in the cases of $10 w-c o u n t$ raw milks than in cases of higher-count milks. This is shown by graph in Figure 1. In adlition a fairly constant number of bacteria survived pasteurization irrespective of the rav-milk counts.

\section{Physiologic Types of Bacteria Found Pefore and After Pasteurization}

Milk samples used for the sturly of physiologic types present were obtained from the group used in the second trial, in which the bacterial count reduction by pasteurization was determined.

In distinguishing the types of bacteria in terms of their physiologic effects on milk two requirements must be met. In the first place, conditions must be such as to bring about the development of all types of organisms in proportions equal, as nearly as possible, to the proportions in which these organisms exist in the milk; and, in the second place, the method of distinguishing the physiologic types must yield results in terms of the effects of the bacteria on milk. In an attempt to meet these requirements the milk samples were plated in standard agar and incubated for three days at $19^{\circ}-21^{\circ} \mathrm{C}$., then for two days at $37^{\circ} \mathrm{C}$. Standard agar was selected as the medium most likely to favor the growth of most types of bacteria in the proportions in which they occur in milk. "Low temperature" incubation followed by incubation at $37^{\circ} \mathrm{C}$. was resorted to in order that the greatest possible growth might be obtained. When this work was begun a study was made comparing incubations of two days at $37^{\circ} \mathrm{C}$., three days at $19-21^{\circ} \mathrm{C}$. ("low temperature"), and three days at $19-21^{\circ} \mathrm{C}$. followed by two days at $37^{\circ} \mathrm{C}$. ("long"). Duplicate plates were made of each dilution. Blanks were plated each time a medium was prepared. One cc. of sterile water was plated with the agar as a check on the sterilization of the medium, dilution water, and equipment. No organisms developed on these plates at any time. The counts found in this study are shown in Table 3. All but two samples of the raw milks showed a higher count on "long" incubation than on standard incubation. All the pasteurized samples yielded the highest counts on "long" incubation, as did all but two of the bottled samples. The counts on "low temperature" incubation are included to show the effect of such incubation on the samples studied. The increases in counts due to "long" incubation were taken as an indication that a truer representation of the types present was obtained due to this procedure than when standard methods were allowed.

In distinguishing the physiologic types grown on these plates by "long" incubation, the "milk-tube method" of Ayres and Johnson (4) was used. This method consisted of picking the colonies from a plate and inoculating inaividually into litmus $1 \mathrm{milk}$, incubating the litmus milk for 14 days at $30^{\circ} \mathrm{C}$, and then classifying the types of bacteria according to their action on the milk as acid-forming, acidcoagulating, alkali-forming, inert, and peptonizing. In this work two additional types were classified: i. e., sweet-curdling and acid- 


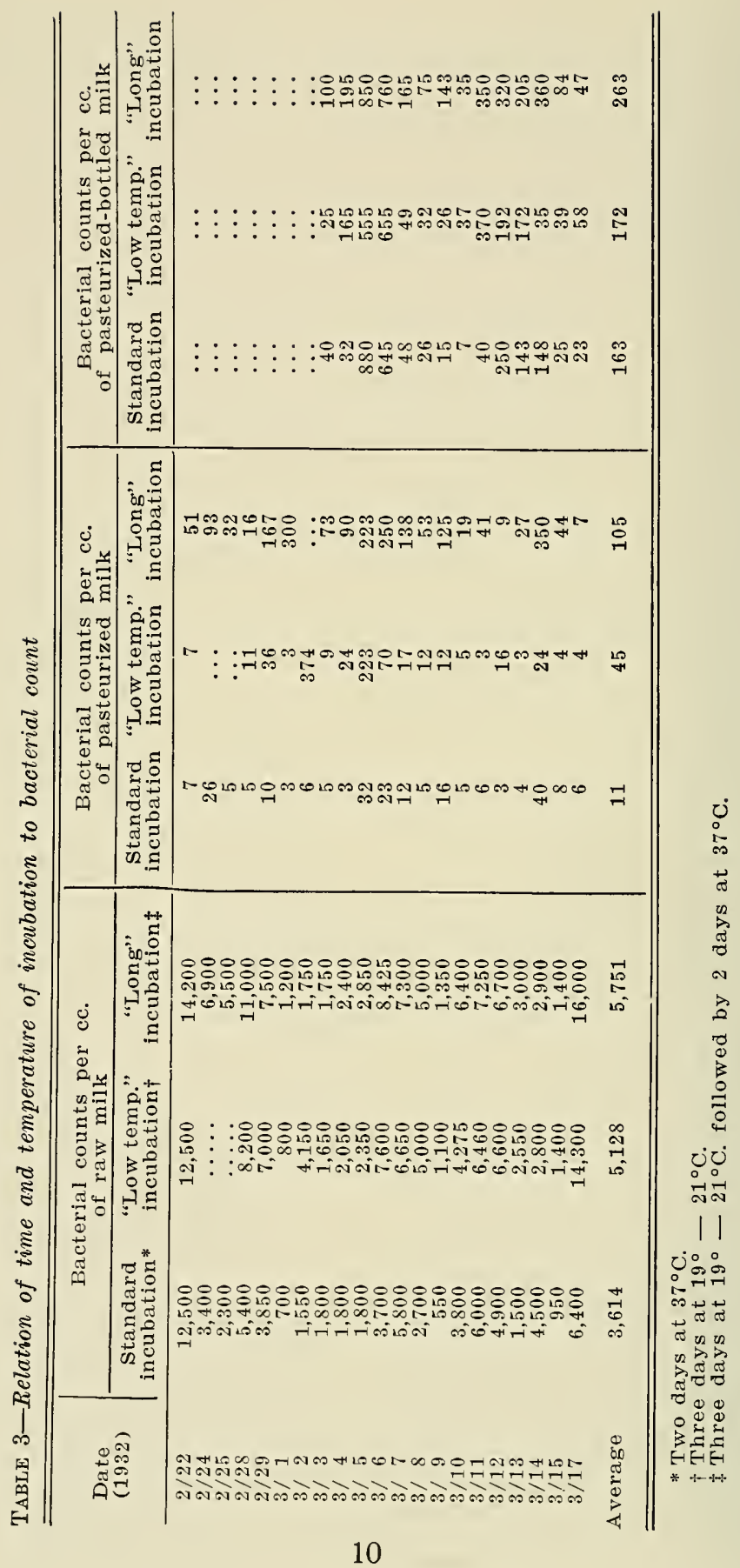


coagulating-peptonizing. The sweet-curdling types were recognized by their coagulation of milk without changing the color of the litmus. The acid-coagulating-peptonizing bacteria showed acid coagulation and a partial digestion of the curd, which had to be distinguished from some acid-coagulating types which caused expelling of whey from the curd but did not produce proteolysis.

The litmus milk used in the milk-tube method was prepared by adding litmus solution to pasteurized skim milk until a deep blue color was evident. The milk was then tubed and sterilized. Some variation in color between batches occurred, but results could be read easily by comparison with a non-inoculated tube incubated with the tubes inoculated from each sample. The non-inoculated tubes never showed evidence of fermentation. Frequent checks were made of the condition of the equipment, medium, and dilution water by plating blanks with $1 \mathrm{cc}$. of the dilution water and incubating with the other plates.

TABLE 4-Standard counts of mill samples used for determination of physiologic types of bacteria

\begin{tabular}{|c|c|c|c|c|}
\hline \multirow{2}{*}{$\begin{array}{l}\text { Range of } \\
\text { bacterial } \\
\text { counts }\end{array}$} & \multirow{2}{*}{$\begin{array}{l}\text { Number of } \\
\text { samples } \\
\text { raw milk }\end{array}$} & \multirow{2}{*}{$\begin{array}{l}\text { Range of } \\
\text { bacterial } \\
\text { counts }\end{array}$} & \multicolumn{2}{|c|}{ Number of samples } \\
\hline & & & $\begin{array}{l}\text { Pasteurized } \\
\text { milk }\end{array}$ & $\begin{array}{l}\text { Bottled } \\
\text { milk }\end{array}$ \\
\hline $\begin{array}{c}\text { per cc. } \\
\text { Below } 2,500 \\
2,500-5,000 \\
5,000-7,500 \\
7,500-10,000 \\
\text { Above } 10,000\end{array}$ & $\begin{array}{l}6 \\
8 \\
3 \\
2 \\
2 \\
2\end{array}$ & $\begin{array}{c}\text { per cc. } \\
\text { Below } 10 \\
10-50 \\
50-200 \\
200-1,000\end{array}$ & $\begin{array}{r}16 \\
4 \\
\cdots \\
\cdots\end{array}$ & $\begin{array}{l}1 \\
8 \\
3 \\
3\end{array}$ \\
\hline 'Total & 21 & & & \\
\hline
\end{tabular}

* One count was 13,500 and the other $\$ 1,200$.

It was planned to pick from 30 to 65 colonies from each sample. Usually all the colonies were picked from one plate. In a few cases, however, dilutions failed to yield a number of colonies within these limits. When the plates from which the colonies were picked contained more than the required number of colonies all of the colonies on a representative portion of the plate were picked. When single plates failed to yield as many as 30 colonies the duplicate plate was picked also, and in some cases of extremely low counts the two duplicate plates failed to yield as many as 30 colonies. Numbers of colonies picked in cases when fewer than 30 were available ranged from 13 to 28 for raw-milk samples, from 9 to 25 for pasteurized samples, and from 15 to 29 for bottled samples.

Twenty-one samples of raw milk were studied in this experiment. As the plating of one of the pasteurized samples was overlooked, results were obtained on only 20 of these samples after pasteurization. Fifteen were studied of the pasteurized botted milk. The average bacterial counts of the milks used were as follows: raw, 8,198; pasteurized, 8; and bottled, 138 per cubic centimeter. Table 4 shows the range of counts of these samples. It will be observed that two raw milks showing counts above 10,000 were used. These 
TABLE 5-Proportions of types of bacteria found in high-grade milk before and after pasteurization and after pumping, cooling, and bottling

\begin{tabular}{|c|c|c|c|}
\hline Types & $\begin{array}{c}\text { Raw milk } \\
(21 \quad \text { samples })\end{array}$ & $\begin{array}{c}\text { Pasteurized } \\
\text { milk } \\
(20 \quad \text { samples })\end{array}$ & $\begin{array}{l}\text { Pasteurized- } \\
\text { bottled milk } \\
(15 \text { samples) }\end{array}$ \\
\hline & $\begin{array}{l}\text { Average of } \\
\text { total colonies }\end{array}$ & $\begin{array}{l}\text { Average of } \\
\text { total colonies }\end{array}$ & $\begin{array}{l}\text { Average of } \\
\text { total colonies }\end{array}$ \\
\hline $\begin{array}{l}\text { Acid-forming } \\
\text { Acid-coagulating } \\
\text { Inert } \\
\text { Alkali-forming } \\
\text { Peptonizing } \\
\text { Acid-coagulating- } \\
\text { peptonizing } \\
\text { Sweet-curdling }\end{array}$ & $\begin{array}{c}\text { percent } \\
18.31 \pm 1.83 \\
49.87 \pm 2.68 \\
20.24 \pm 1.50 \\
5.02 \pm 0.65 \\
4.31 \pm 0.73 \\
1.97 \pm 0.87 \\
0.28 \pm 0.12\end{array}$ & $\begin{array}{c}\text { percent } \\
48.01 \pm 2.97 \\
18.85 \pm 3.17 \\
18.05 \pm 1.97 \\
0.71 \pm 0.24 \\
8.60 \pm 1.46 \\
5.78 \pm 1.15 \\
0\end{array}$ & $\begin{array}{l}\text { percent } \\
33.30 \pm 3.61 \\
33.18 \pm 4.06 \\
14.03 \pm 3.63 \\
3.60 \pm 0.66 \\
10.07 \pm 2.01 \\
5.77 \pm 1.82 \\
0\end{array}$ \\
\hline Total & 100.00 & 100 & 100 \\
\hline
\end{tabular}

were not eliminated from consideration because such counts are to be expected occasionally even under well-controlled conditions. The proportions of physiologic types found in these two samples did not show any more marked variation from the average distribution of types than did some of the samples with counts below 10,000.

Results of the study of the proportions of physiologic types of bacteria found in these samples are given in Table 5 and Figure 2. The outstanding change in the proportions of types caused by pasteurization was between the acid-forming and acid-coagulating groups. The proportion of acid-forming bacteria increased from

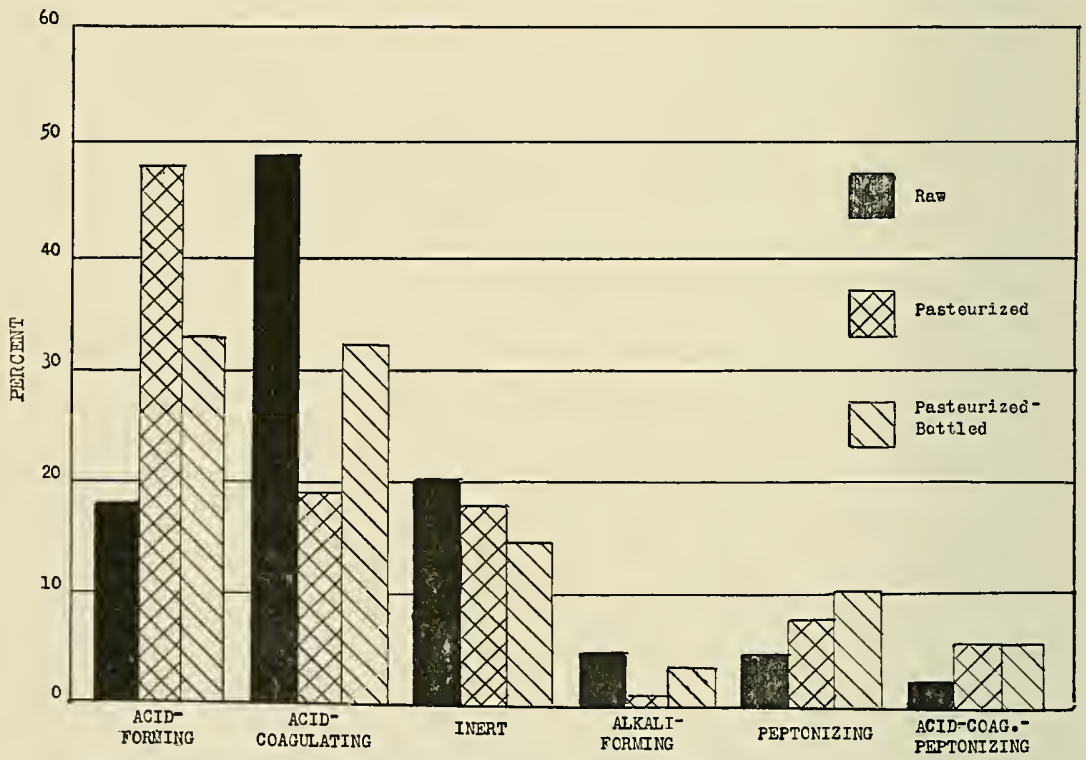

Fig. 2-A comparison of the percentages of physiologic types of bacteria found in raw, pasteurized, and pasteurized-bottled high-grade milks 
$18.31 \pm 1.83$ to $48.01 \pm 2.97$ percent on pasteurization, whereas the acid-coagulating group decreased from $52.22 \pm 2.68$ to $19.66 \pm 3.17$ percent. The proportions of inert and peptonizing organisms did not change significantly as a result of pasteurization. Only three colonies that produced sweet curdling were found and these were in the raw milk. The proportions of types in the bottled milk showed that the contamination resulting from pumps, pipes, cooler, and bottler was largely of the acid-forming, acid-coagulating, and peptonizing types. The proportions of the contaminating types calculated on the basis of percentages of types and average counts of the pasteurized and bottled milks are shown in Table 6 .

TABLE 6-Calculated proportions of types of bacteria contaminating pasteurized mills in pumping, cooling, and bottling

\begin{tabular}{|c|c|}
\hline Types & $\begin{array}{c}\text { Average } \\
\text { contamination }\end{array}$ \\
\hline $\begin{array}{l}\text { Acid-forming } \ldots \ldots \ldots \ldots \ldots \ldots \ldots \ldots \ldots \\
\text { Acid-coagulating } \ldots \ldots \ldots \ldots \ldots \\
\text { Inert }{ }_{\text {Alkali-forming }} \ldots \ldots \ldots \ldots \ldots \ldots \ldots \\
\text { Peptonizing } \ldots \ldots \ldots \ldots \ldots \\
\text { Acid-coagulating-peptonizing } \ldots \ldots \ldots\end{array}$ & $\begin{array}{l}\text { percent } \\
32.48 \\
37.78 \\
12.34 \\
3.47 \\
9.12 \\
4.81\end{array}$ \\
\hline
\end{tabular}

Morphologic Types of Bacteria in Milk

Before and After Pasteurization

When trial 1 of the study of reduction in bacterial counts by pasteurization was conducted, colonies were picked from each sample of raw and of pasteurized milk, inoculated into sterile litmus milk, and incubated for 14 days at $30^{\circ} \mathrm{C}$. After noting the types of reactions in litmus milk, the cultures were smeared and stained with methylene blue. The stained slides were examined and the forms noted and classified into three groups: viz., coccus, bacillus, and streptococcus. Results of this study are shown in Table 7 and Figure 3 .

TABLE 7-Proportions of morphologic types of bacteria in raw and pasteurized mill:

\begin{tabular}{lcccc}
\hline \hline \multirow{2}{*}{ Form } & \multicolumn{2}{c}{ Raw milk } & \multicolumn{2}{c}{ Pasteurized } \\
\cline { 2 - 5 } & $\begin{array}{c}\text { Number of } \\
\text { colonies }\end{array}$ & Percent & $\begin{array}{c}\text { Number of } \\
\text { colonies }\end{array}$ & Percent \\
\hline Coccus & 103 & 47.25 & 52 & 47.27 \\
Bacillus & 38 & 17.43 & 51 & 46.37 \\
Streptococcus & 77 & 35.82 & 7 & 100 \\
Total & 218 & 100 & 110 & 100 \\
\hline \hline
\end{tabular}

Coccus forms are shown not to have changed due to pasteurization, but a marked increase of bacillus forms and a corresponding decrease of streptococcus forms occurred. It was found that the bacillus forms were predominantly acid-formers, while the streptococcus forms were largely acid-coagulators. 


\section{SUMMARY AND CONCLUSIONS}

The results herein reported give an indication of the bacterial flora of milks, the majority of which were low enough in count to meet the bacterial requirement for certification. They also give an indication of the effect of pasteurization on the flora of such milks, and of the contaminating flora under optimum conditions of pumping, cooling, and bottling. The possibility that the medium used may not have permitted the development of all types of organisms in the proportion in which they occurred in the milks must, however, be admitted.

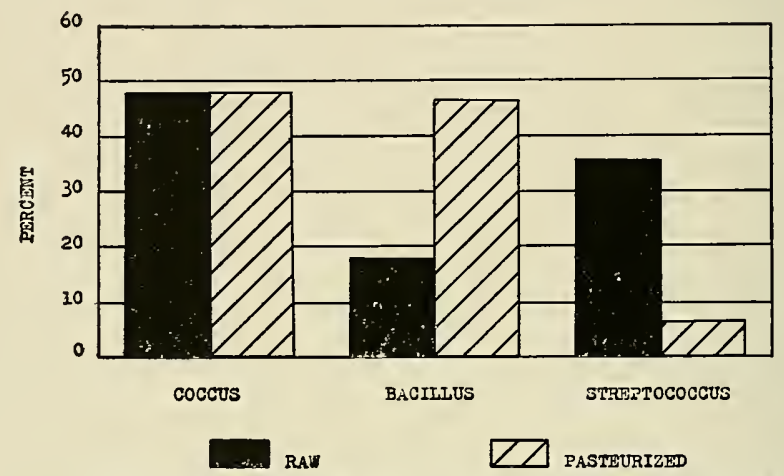

FIG. 3-A comparison of the morphologic types of bacteria found in raw and pasteurized high-grade milks

Data of two trials, studying percentage reduction in bacterial count due to pasteurization, show a striking difference between the two trials in percentage reduction of counts due to pasteurization, greater reduction being attained in the second trial. The evidence suggests that the greater reduction in the second trial was made possible by more complete sterilization of the pasteurizer. Although a chlorine rinse was used throughout a part of the second trial, the fact that results were equally good during a period of two weeks when chlorine treatment was omitted indicates that some other factor was responsible for the change in percentage destruction of bacteria by pasteurization. After the first trial was completed, the packing around the shaft of the pasteurizer agitator was found to be in bad condition and leaking. This was repaired before the second trial was started and probably offers the correct explanation for the greater part of the differences found in efficiency of reduction in bacterial count as the result of pasteurization.

The results indicate that it is possible to reduce the standard plate count of low-count raw milk more than 99 percent by pasteurization. They also indicate that a fairly constant number of bacteria survived pasteurization irrespective of the counts of the raw milk. In considering this fact, however, it should be remembered that no exceptionally high-count raw milks were pasteurized in these experiments. 
Results of the determination of physiologic types showed that the greatest number of the bacteria in these milks that grew under the conditions set up were acid-forming and acid-coagulating types (66.18 percent in the raw milks, 66.86 in the pasteurized milks, and 66.48 in the pasteurized-bottled milks). It is significant that pasteurization destroyed a higher percentage of the acid-coagulating bacteria than of the acid-forming organisms. A probable explanation for this result was found in the study of the morphologic types in which it was found that most of the acid-forming bacteria were bacilli. As many of the bacilli are spore formers, their heat-resistance was to be expected.

In view of the statement often heard that "pasteurized milk will rot without souring", the proportions of peptonizing bacteria found in these milks are of special interest. There was a slight increase of this type due to pasteurization, and a significant increase in the bottled milks. A study of the growth of physiologic types on storage at various temperatures is reported in Part II of this bulletin.

Results of the study of the morphologic types of bacteria in highgrade milk before and after pasteurization indicate that there must have been several resistant types of cocci in the raw milk, as the proportion is shown not to have changed to any significant extent by pasteurization. As many bacilli are of the spore-forming types, the increase in the proportion of the bacillus forms in the pasteurized milk was to be expected. Pin-point colonies on plates from pasteurized milk may be from the Streptococcus thermophilus group, but as no predominance of pin-point colonies was noted at any time, it is assumed that the streptococci present were of the Streptococcus lactis type, and as this type is largely destroyed by pasteurization, the great reduction in the proportion of streptococci found in this experiment was to be expected.

PART II. Changes in Standard Count, Acidity, Flavor, and Physiologic Trpes of Bacteria Due to Storage at Various Temperatures

Considerable attention is given to the production of high-grade raw milk which is sold as a Certified or Grade-A product. Information regarding the changes in such milk on storage is meager, however, and less is known of the keeping qualities of high-grade milk that has been pasteurized. Statements, many of which are not based on sound evidence, are often heard in favor of pasteurization or nonpasteurization of Certified or Grade-A milk. This study was undertaken in order to procure experimental evidence as to the changes in plate count, ecidity, flavor, and proportions of physiologic types of bacteria of low-count raw, pasteurized, and pasteurized-bottled milks at various temperatures of storage. Ayres and Johnson (2) pasteurized one sample each of "poor", "medium", and "excellent" raw milks to determine the changes in bacterial flora of the pasteurized milks on storage at room temperature, $70^{\circ}-75^{\circ} \mathrm{F}$. $\left(21.1-23.9^{\circ} \mathrm{C}\right.$.), and 
at ice-box temperature, $46.4^{\circ}-50^{\circ} \mathrm{F} .\left(8-10^{\circ} \mathrm{C}\right.$. $)$. Differentiation of types was made by the litmus "milk-tube method". The sample of poor-grade milk held at room temperature showed a rennet curd on the third day. This followed a rapid development of peptonizing bacteria. On storage at room temperature the counts and acidities of these samples increased rapidly after the second or third day, whereas the increases were greatly retarded by storage in the ice box. In the "excellent" and "poor" samples the peptonizing bacteria overgrew the other types at room temperature, but were restrained in all three samples by storage at the ice-box temperature. Changes in proportions of types of organisms were slight during the first few days of storage in the ice box irrespective of the counts of the raw milks before pasteurization, after which the proportions of alkaliforming organisms increased somewhat.

Black, Prouty, and Graham (3) recently have determined the physiologic types of organisms in 20 samples of low-count milk before and after pasteurization in flasks and in the same milks after storage at $68^{\circ} \mathrm{F} .\left(19.9^{\circ} \mathrm{C}\right.$.) and at $45^{\circ} \mathrm{F} .\left(7.1^{\circ} \mathrm{C}\right.$. $)$, until an off-flavor had developed with the result that the milk was unfit for consumption. Differentiation of types was made on Bacto-nutrient-caseinateagar containing brom cresol purple. Inert and alkali-forming types were grouped together. The raw milks stored at $68^{\circ} \mathrm{F}$. showed an increase of the acid-forming type and a decrease of the alkali-forming and inert types, but practically no change of the percentage of peptonizing bacteria. The pastenrized milks stored at $68^{\circ} \mathrm{F}$. and the raw and pasteurized milks stored at $45^{\circ} \mathrm{F}$. showed significant increases of proportions of peptonizing organisms. The proportion of acid-forming bacteria increased in the raw milks stored at $45^{\circ} \mathrm{F}$. but showed no marked change in the pasteurized milks stored at $68^{\circ}$ and $45^{\circ} \mathrm{F}$. The alkali-forming and inert group decreased slightly in the pasteurized milks stored at $45^{\circ} \mathrm{F}$. and markedly both in the raw milks. at this temperature and in the pasteurized milks stored at $68^{\circ} \mathrm{F}$. Acidity increased more rapidly in the raw than in the pasteurized milks.

That the storage temperature exerts a striking influence on the keeping quality of milk is shown by North (15), Ross (21), and Hammer (8), the last-mentioned observing that the storage temperature not only determines the rate of bacterial development but also has an effect on the types of organisms that develop, $70^{\circ} \mathrm{F} .\left(21.1^{\circ} \mathrm{C}\right.$.) being ideal for the development of S. lactis, which quickly outgrows the other organisms that may be present. Hammer also noted that the percentage increase in clean raw milk is less than in dirty milk because a greater portion of the bacteria in clean milk tend to be of the inert type.

Heineman and Glenn (11), Hammer (8), and others have shown that a germicidal period occurs in fresh raw milk, but agree that this inhibiting influence lasts but a short time and consequently is of little practical importance. 
The milk used in this investigation was produced and processed under conditions as described in Part I of this bulletin.

A study was made of the changes of bacterial count, acidity. and flavor on storage at various temperatures, and later a study of the changes of physiologic types of organisms, acidity, and flavor on storage at various temperatures was carried out.

\section{Effect of Storage at Various Temperatures on Plate Count, Acidity, and Flavor}

Four deliveries of milk were studied immediately before and immediately after pasteurization. In each case three one-quart samples of raw milk were taken from the pasteurizer just before pasteurization. Sterile equipment was used, and the necessary precautions to prevent contamination were observed. These samples were held in a cooler until the remainder of the milk had been pasteurized, when three more samples were taken in a similar manner.

The samples of pastenrized milk were cooled by setting the bottles in warm water and gradually lowering the temperature by introducing a small stream of cold water. After cooling, a pair of samples, one of raw and one of pasteurized milk, was placed in a water bath and adjusted to a temperature of $45^{\circ} \mathrm{F}$. $\left(7.2^{\circ} \mathrm{C}\right.$. $)$. Another pair was similarly adjusted to a temperature of $70^{\circ} \mathrm{F} .\left(21.1^{\circ} \mathrm{C}\right.$.), and the third pair to a temperature of $98.6^{\circ} \mathrm{F} .\left(37^{\circ} \mathrm{C}\right.$.).

The pair of samples adjusted to a temperature of $70^{\circ} \mathrm{F}$. was then placed in an insulated box where a temperature of $70^{\circ} \mathrm{F}$. was maintained. The samples adjusted to a temperature of $98.6^{\circ} \mathrm{F}$. were placed in an incubator, where this temperature was maintained. The third pair of samples was used for determining the initial acidity and bacterial count of the raw and pasteurized milk before being placed in a cooler at $45^{\circ} \mathrm{F} .\left(7.2^{\circ} \mathrm{C}\right.$.), where they were held.

The samples held at $70^{\circ} \mathrm{F}$. $\left(21.1^{\circ} \mathrm{C}\right.$.) and those held at $98.6^{\circ} \mathrm{F}$. $\left(37^{\circ} \mathrm{C}\right.$.) were plated every four hours, while the samples held at $45^{\circ} \mathrm{F}$. $\left(7.2^{\circ} \mathrm{C}\right.$. $)$ were plated every day. In plating and counting, the macroscopic colony count method outlined by Standard Methods of Milk Analysis (1) was followed, except that the agar used contained $1 \%$ lactose. Plating was discontinued in each case after coagulation had occurred. The acidity of each sample was determined at the time of plating by titrating a $17.6 \mathrm{cc}$. portion with $\mathrm{N} / 10$ sodium hydroxide, using phenolphthalein as an indicator and calculating the acidity as percent lactic acid. Observations were also made of the types of curd formed in the coagulated samples as an indication of the types of fermentation that had taken place in the various samples.

The data recorded in Table 8 show the average changes of acidity and bacterial counts for four trials involving the same methods. The changes progressed uniformly in each trial. The acidity and 
bacterial count increased in proportion to the storage temperature in every case. At $45^{\circ} \mathrm{F}$. and at $70^{\circ} \mathrm{F}$. the bacterial counts of the raw milks were higher than those of the pasteurized milks at every stage of the storage period, whereas at $98.6^{\circ} \mathrm{F}$. the bacterial counts of the pasteurized milks were considerably higher than those of the raw milks after storage for 8,12 , and 16 hours.

TABLE 8-The effect of storage temperature on rate of acid production and bacterial-count increase in raw and pasteurized milks (Average of four trials)

\begin{tabular}{|c|c|c|c|c|c|c|}
\hline \multirow{3}{*}{$\begin{array}{l}\text { Storage } \\
\text { period }\end{array}$} & \multicolumn{6}{|c|}{ Acidity } \\
\hline & \multicolumn{3}{|c|}{ Raw milks stored at } & \multicolumn{3}{|c|}{ Pasteurized milks stored at } \\
\hline & $45^{\circ} \mathrm{F}$ & $70^{\circ} \mathrm{F}$ & $98.6^{\circ} \mathrm{F}$ & $45^{\circ} \mathrm{F}$. & $70^{\circ} \mathrm{F}$ & $98.6^{\circ} \mathrm{F}$. \\
\hline $\begin{aligned} 0 & \\
4 & \text { Hrs. } \\
8 & \text { “، } \\
12 & \text { “، } \\
16 & \text { “ } \\
20 & \text { “ } \\
24 & \text { “ } \\
28 & \text { “ } \\
32 & \text { “ } \\
36 & \text { days } \\
2 & \text { “ } \\
3 & \text { “ } \\
4 & \text { “ } \\
5 & \text { “ } \\
6 & \text { “، } \\
7 & \text { “ } \\
8 & \end{aligned}$ & $\begin{array}{l}0.175 \\
\ldots \ldots \\
\ldots \ldots \\
\ldots \ldots \\
0.177 \\
\ldots \ldots \\
\ldots \\
0.187 \\
0.195 \\
0.25 \\
0.325 \\
0.37 \\
0.45 \\
0.525\end{array}$ & $\begin{array}{l}0.175 \\
0.18 \\
0.182 \\
0.185 \\
0.187 \\
0.192 \\
0.197 \\
0.205 \\
0.25 \\
0.30 \\
0.80 \\
0.92 \\
\ldots \ldots \\
\ldots \ldots \\
\ldots \ldots \\
\ldots \ldots\end{array}$ & $\begin{array}{l}0.175 \\
0.185 \\
0.19 \\
0.21 \\
0.275 \\
0.725 \\
0.845 \\
0.855 \\
\ldots \ldots \\
\ldots \ldots \\
\ldots \ldots \\
\ldots \ldots \\
\ldots \ldots \\
\ldots \ldots\end{array}$ & $\begin{array}{c}0.175 \\
\ldots \ldots \\
\ldots \ldots \\
\ldots \ldots \\
0.175 \\
\ldots \ldots \\
\ldots \ldots \\
0.18 \\
0.18 \\
0.18 \\
0.17 \\
0.17 \\
0.17 \\
0.17\end{array}$ & $\begin{array}{l}0.175 \\
0.175 \\
0.175 \\
0.175 \\
0.175 \\
0.175 \\
0.175 \\
0.175 \\
0.185 \\
0.19 \\
0.255 \\
0.735 \\
\ldots \ldots \\
\ldots \ldots \\
\ldots \ldots \\
\ldots \ldots\end{array}$ & $\begin{array}{l}0.175 \\
0.175 \\
0.185 \\
0.19 \\
0.20 \\
0.485 \\
0.585 \\
0.655 \\
\ldots \ldots \\
\ldots \ldots \\
\ldots \ldots \\
\ldots \ldots \\
\ldots \ldots \\
\ldots \ldots\end{array}$ \\
\hline
\end{tabular}

TABLE 8-Continued

\begin{tabular}{|c|c|c|c|c|c|c|}
\hline \multirow{3}{*}{$\begin{array}{l}\text { Storage } \\
\text { period }\end{array}$} & \multicolumn{6}{|c|}{ Bacterial counts } \\
\hline & \multicolumn{3}{|c|}{ Raw milks stored at } & \multicolumn{3}{|c|}{ Pasteurized milks stored at } \\
\hline & $45^{\circ} \mathrm{F}$ & $70^{\circ} \mathrm{F}$ & $98.6^{\circ} \mathrm{F}$. & $45^{\circ} \mathrm{F}$ & $70^{\circ} \mathrm{F}$. & $98.6^{\circ} \mathrm{F}$. \\
\hline 0 & 15,000 & 15,000 & 15,000 & 600 & 600 & 600 \\
\hline $4 \mathrm{Hrs}$. & $\ldots, \ldots$ & 53,000 & 374,000 & ... & 1,000 & 15,000 \\
\hline 8 " & $\ldots \ldots$ & 783,000 & $3,350,000$ & $\because$ & 8,000 & $10,200,00$ ? \\
\hline 12 " & $\ldots \ldots$ & $6,730,000$ & $58,600,000$ & $\ldots$ & 98,000 & $109,000,000$ \\
\hline 16 & $\ldots \ldots$ & $4,373,000$ & $245,000,000$ & $\cdots$ & 580,000 & $585,000,000$ \\
\hline 20 & & $9,024,000$ & $\ldots \ldots \ldots$ & & $1,183,000$ & $\ldots \ldots \ldots$ \\
\hline 24 & 25,000 & $69,000,000$ & $\ldots \ldots \ldots$ & 1,200 & $1,873,000$ & $\ldots \ldots \ldots$ \\
\hline 28 & $\ldots \ldots$ & $262,000,000$ & $\ldots \ldots \ldots$ & $\ldots$ & $21,388,000$ & $\ldots \ldots \ldots$ \\
\hline 32 & $\ldots \ldots$ & $\ldots \ldots \ldots$ & $\ldots \ldots \ldots$ & $\ldots$ & $16,377,000$ & $\ldots \ldots \ldots$ \\
\hline 36 " & 116000 & $\ldots \ldots \ldots$ & $\ldots \ldots \ldots$ & $\ddot{0} \ddot{n} \dot{0}$ & $17,312,000$ & $\ldots \ldots \ldots$ \\
\hline 2 days & 116,000 & $\ldots \ldots \ldots$ & $\ldots \ldots \ldots$ & 2,000 & $\ldots \ldots \ldots$ & $\ldots \ldots \ldots$ \\
\hline $\begin{array}{ll}3 & 16 \\
4 & \text {. }\end{array}$ & 591,000 & $\ldots \ldots \ldots$ & $\cdots \cdots \cdots$ & 10,000 & $\ldots \ldots \ldots$ & $\ldots \ldots \ldots$ \\
\hline$\frac{4}{5}$ “ & $\begin{array}{l}22,000,000 \\
52,000,000\end{array}$ & $\cdots \cdots \cdots$ & $\cdots \ldots \ldots$ & $\begin{array}{r}72,000 \\
171,000\end{array}$ & $\cdots \cdots \cdots$ & $\cdots \cdots \cdots$ \\
\hline " & $79,000,000$ & $\because \ldots \ldots \ldots$ & $\cdots \cdots$ & 410,000 & $\cdots \cdots \cdots$ & $\cdots \cdots \cdots$ \\
\hline " & $23,000,000$ & $\ldots \ldots$ & $\ldots \ldots$ & $1,445,000$ & - & $\cdots$ \\
\hline " & $277,000,000$ & $\ldots \ldots \ldots$ & $\ldots \ldots \ldots$ & $1,600,000$ & $\ldots \ldots \ldots$ & (e \\
\hline
\end{tabular}

The samples stored at $45^{\circ} \mathrm{F}$. developed slightly unclean flavors on the fourth day, whereas the pasteurized milks developed on offflavors until the fifth day, when the raw milks were considered unmarketable. No very objectionable flavors or odors developed in the pasteurized milks until the seventh day, when they were slightly stale and unclean.

A slightly old and slightly unclean flavor had developed in the raw milks held at $70^{\circ} \mathrm{F}$. after 16 hours, and after 24 hours the milks 
were considered unmarketable. Deterioration was rapid after this time, and the milks coagulated after storage for 28 and 36 hours. The pasteurized milks stored at $70^{\circ} \mathrm{F}$. had developed only slightly objectionable flavors after storage for 24 hours and these milks did not become unmarketable until after 28 to 36 hours' storage.

All samples stored at $98.6^{\circ} \mathrm{F}$. deteriorated rapidly. The pasteurized milks remained fit for consumption longer than the raw milks; however, the former showed only slightly objectionable flavors and odors after storage for 12 hours, whereas the latter were old and unclean in flavor after storage for 8 hours.

The types of curd formed by the pasteurized milks differed from that formed by the raw milks. Irrespective of the storage temperature the raw milks produced typical acid curds with little or no gas and no whey. The pasteurized milks invariably coagulater at low acidities - in one case at 0.28 percent acid - and whey was expelled from the curd in a manner similar to that observed when milk is coagulated by rennin. In addition these curds were somewhat gassy.

\section{Changes of Relation of Storage at Various Temperatures}

to Proportions of Physiologic Types of Bacteria on Storage at Various Temperatures

Six samples of milk were studied both raw and after pasteurizing, pumping, cooling, and bottling in the Station creamery under commercial conditions. The raw milk samples were taken from the vat just before pasteurization. In each case the raw milk was dipped with a sterile dipper into a half-pint milk bottle previously treated with flowing steam for 30 minutes in a steam chest and left inverted to cool. The bottles were capped by hand, care being taken to avoid contamination. These samples were used for storage and subsequent analysis. A sample for immediate analysis was taken by means of a sterile sampling tube, placed in a sterile culture tube and held at $40^{\circ} \mathrm{F}$. $\left(4.4^{\circ} \mathrm{C}\right.$.) until the bottled sample could be obtained. The samples of bottled milk were taken in half-pint bottles, machine-filled, and capped as nearly half-way through the bottling procedure as possible. These bottles, like those used for the raw-milk samples, had been steamed previously in a steam chest. The samples of raw and pasteurized-bottled milk were then set away at the storage temperature or temperatures. one bottle of raw and one of pasteurized-bottled milk being stored for each day's analysis throughout the storage period.

The distribution of physiologic types was determined by a modification of the litmus "milk-tube method" of Ayres and Tohnson (2). This modification is described in detail in Part I of this bulletin. It differs from the original method in that standard agar (1) was used rather than beef infusion or casein agar, and plates were incubated for three davs at $19^{\circ}-21^{\circ} \mathrm{C}$., then for two days at $37^{\circ} \mathrm{C}$. Colonies were then picked into tubes of sterile litmus milk and in- 
cubated, together with an uninoculated or check tube, for 14 days at $30^{\circ} \mathrm{C}$., after which the results were read. After each sample had been plated the titratable acidity was determined, and observations of the flavor and odor were recorded.

The storage temperatures used were selected to fit ranges likely to be found in practice when such milk is handled commercially and kept in the home. One storage temperature ranged from $36^{\circ}-40^{\circ} \mathrm{F}$. $\left(2.2^{\circ}-4.4^{\circ} \mathrm{C}.\right)$, another from $41^{\circ}-46^{\circ} \mathrm{F} .\left(4.9-7.7^{\circ} \mathrm{C}\right.$. $)$, and the third from $53^{\circ}-56^{\circ} \mathrm{F}$. $\left(11.5^{\circ}-13.2^{\circ} \mathrm{C}\right.$. $)$. Because of the time consumed in applying the "milk-tube" method it was found impossible to study the effect of storage on each set of samples at all three of these temperature ranges. Four sets of samples were held at the higher temperature, two at $41^{\circ}-46^{\circ} \mathrm{F}$., and two at $36^{\circ}-40^{\circ} \mathrm{F}$. Two of the sets were kept simultaneously at $36^{\circ}-40^{\circ} \mathrm{F}$. and at $53^{\circ}-56^{\circ} \mathrm{F}$. Because milk usually is not stored longer, the storage period in every case was four days.

RAW MILK

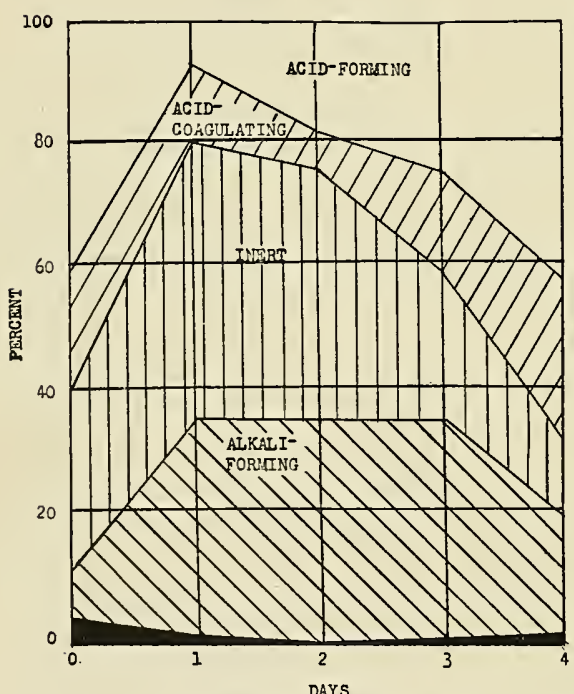

MILK PASTEURIZED AND BOTTLED 100

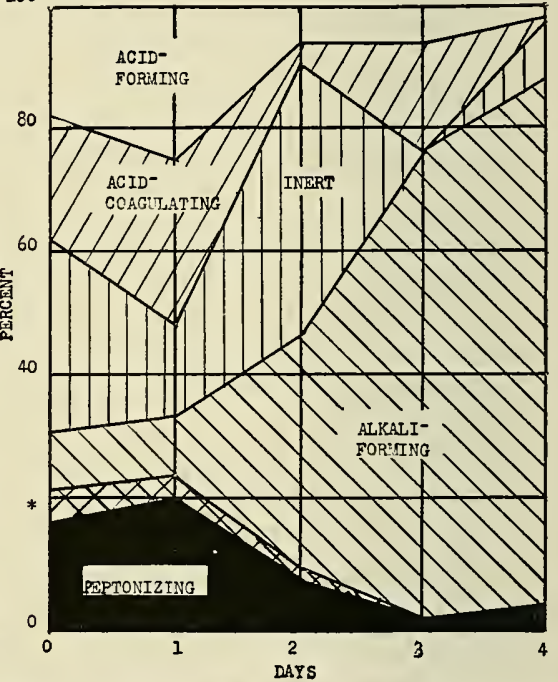

FIG. 4-Daily changes of the proportions of the physiologic types of bacteria in high-grade milk on storage for four days at $53^{\circ}$ to $56^{\circ} \mathrm{F}$.

* Acid-coagulating-peptonizing.

The changes in bacterial counts and acidities are summarized in Tables 9 and 10. The bacterial counts were found to increase at all the storage temperatures at. rates roughly proportional to the holding temperature. Increases were rapid both in the raw and pasteurized-bottled samples stored at $53^{\circ}-56^{\circ} \mathrm{F}$, but growth was retarded at the two lower temperatures. The counts of the pasteurized- 
bottled milks stored at $36^{\circ}-40^{\circ} \mathrm{F}$. showed no significant increase throughout the holding period.

The percentage of lactic acid increased slightly in all samples. Even though the counts of the raw-milk samples stored at $53^{\circ}-56^{\circ} \mathrm{F}$. increased rapidly, the acidity increased slowly during the four-day holding period. In the case of the pastenrized-bottled samples stored at $36^{\circ}-40^{\circ} \mathrm{F}$, the acidities increased slightly during the four-day holding period, while the bacterial counts did not show a significant increase.

Flavor changes of the raw-milk samples usually occurred on the third or fourth day of storage. In all but one sample the flavor became stale and old at or near the time the stage of accelerative growth of the bacteria occurred. One sample stored at $53^{\circ}-56^{\circ} \mathrm{F}$. was stale in flavor after holding two days, whereas the other three samples stored at this temperature remained good until the third day. Samples stored at $41^{\circ}-46^{\circ} \mathrm{F}$. became stale on the third day. Those stored at $36^{\circ}-40^{\circ} \mathrm{F}$. did not become stale during the four-day holding period, but one samp!e was slightly rancid on the fourth day, and the sample from the same source, stored at $53^{\circ}-56^{\circ} \mathrm{F}$., which became stale on the second day, was rancid on the fourth day.

TABLE 9-Summary of bacterial counts and acidities of raw milk samples stored at various temperatures

\begin{tabular}{|c|c|c|c|c|c|c|}
\hline \multirow{2}{*}{$\begin{array}{l}\text { Days in } \\
\text { storage }\end{array}$} & \multicolumn{2}{|c|}{$\begin{array}{c}\text { Two samples } \\
\text { stored at } 36^{\circ}-40^{\circ} \mathrm{F} \text {. }\end{array}$} & \multicolumn{2}{|c|}{$\begin{array}{l}\text { Two samples } \\
\text { stored at } 41^{\circ}-46^{\circ} \mathrm{F} \text {. }\end{array}$} & \multicolumn{2}{|c|}{$\begin{array}{l}\text { Four samples } \\
\text { stored at } 53^{\circ}-56^{\circ} \mathbf{F} \text {. }\end{array}$} \\
\hline & $\begin{array}{c}\text { Average } \\
\text { acidity }\end{array}$ & $\begin{array}{c}\text { Average } \\
\text { count* }\end{array}$ & $\begin{array}{l}\text { Average } \\
\text { acidity }\end{array}$ & $\begin{array}{l}\text { Average } \\
\text { count* }\end{array}$ & $\begin{array}{c}\text { Average } \\
\text { acidity }\end{array}$ & $\begin{array}{c}\text { Average } \\
\text { count* }\end{array}$ \\
\hline $\begin{array}{l}0 \\
1 \\
2 \\
3 \\
4\end{array}$ & $\begin{array}{c}\text { percent } \\
0.18 \\
0.18 \\
0.182 \\
0.185 \\
0.185\end{array}$ & $\begin{array}{r}\text { per cc. } \\
8,250 \\
5,150 \\
13,900 \\
199,250 \\
4,531,000\end{array}$ & $\begin{array}{c}\text { percent } \\
0.175 \\
0.182 \\
0.187 \\
0.187 \\
0.187\end{array}$ & $\begin{array}{r}\text { per ce. } \\
7,560 \\
13,300 \\
237,975 \\
2,620,000 \\
5,260,000\end{array}$ & $\begin{array}{c}\text { percent } \\
0.18 \\
0.18 \\
0.184 \\
0.187 \\
0.191\end{array}$ & $\begin{array}{r}\text { per cc. } \\
10,400 \\
110,425 \\
4,544,250 \\
14,000,000 \\
40,212,500\end{array}$ \\
\hline
\end{tabular}

*Incubation for 3 days at $19^{\circ}-21^{\circ} \mathrm{C}$. followed by 2 days at $37^{\circ} \mathrm{C}$.

TABLE 10-Summary of bacterial counts and acidities of pasteurized-bottled samples stored at various temperatures

\begin{tabular}{|c|c|c|c|c|c|c|}
\hline \multirow{2}{*}{$\begin{array}{l}\text { Days in } \\
\text { storage }\end{array}$} & \multicolumn{2}{|c|}{$\begin{array}{c}\text { Two samples } \\
\text { stored at } 36^{\circ}-40^{\circ} \mathrm{F} \text {. }\end{array}$} & \multicolumn{2}{|c|}{$\begin{array}{l}\text { Two samples } \\
\text { stored at } 41^{\circ}-46^{\circ} \mathrm{F} \text {. }\end{array}$} & \multicolumn{2}{|c|}{$\begin{array}{c}\text { Four samples } \\
\text { stored at } 53^{\circ}-56^{\circ} \mathrm{F} \text {. }\end{array}$} \\
\hline & $\begin{array}{l}\text { Average } \\
\text { acidity }\end{array}$ & $\begin{array}{l}\text { Average } \\
\text { count* }\end{array}$ & $\begin{array}{l}\text { Average } \\
\text { acidity }\end{array}$ & $\begin{array}{l}\text { Average } \\
\text { count* }\end{array}$ & $\begin{array}{l}\text { Average } \\
\text { acidity } \\
\end{array}$ & $\begin{array}{c}\text { Average } \\
\text { count* }\end{array}$ \\
\hline $\begin{array}{l}0 \\
1 \\
2 \\
3\end{array}$ & $\begin{array}{c}\text { percent } \\
0.175 \\
0.177 \\
0.18 \\
0.18\end{array}$ & $\begin{array}{c}\text { per cc. } \\
16 \\
\mathbf{3 1} \\
\mathbf{1 2} \\
\mathbf{3 3}\end{array}$ & $\begin{array}{c}\text { percent } \\
0.162 \\
0.165 \\
0.167 \\
0.167 \\
\end{array}$ & $\begin{array}{c}\text { per cc. } \\
119 \\
111 \\
330 \\
12,017 \\
\end{array}$ & $\begin{array}{c}\text { percent } \\
0.174 \\
0.175 \\
0.176 \\
0.177 \\
\end{array}$ & $\begin{array}{r}\text { per cc. } \\
338 \\
171 \\
24,034 \\
510,500 \\
\end{array}$ \\
\hline
\end{tabular}

*Incubation for 3 days at $19^{\circ}-21^{\circ} \mathrm{C}$. followed by 2 days at $37^{\circ} \mathrm{C}$.

All but one sample of the pasteurized-bottled milk became "cappy" in flavor on the third day. The one sample that did not become "cappy" was fine in flavor on the fourth and last day of storage. This sample was stored at $53^{\circ}-56^{\circ} \mathrm{F}$. The count of this sample increased from 22 to 70,000 between the second and third days, while the duplicate sample stored at $36-40^{\circ} \mathrm{F}$. became "cappy" 
RAW MILK

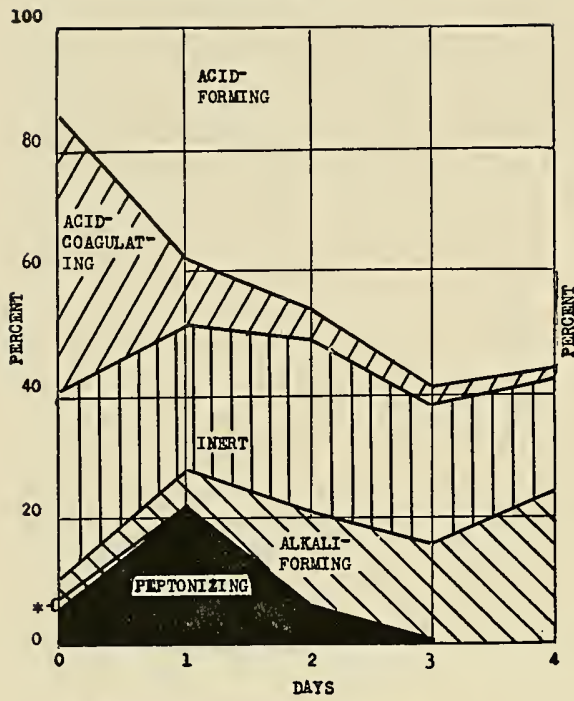

MILK PASTEURIZED AND BOTTLED

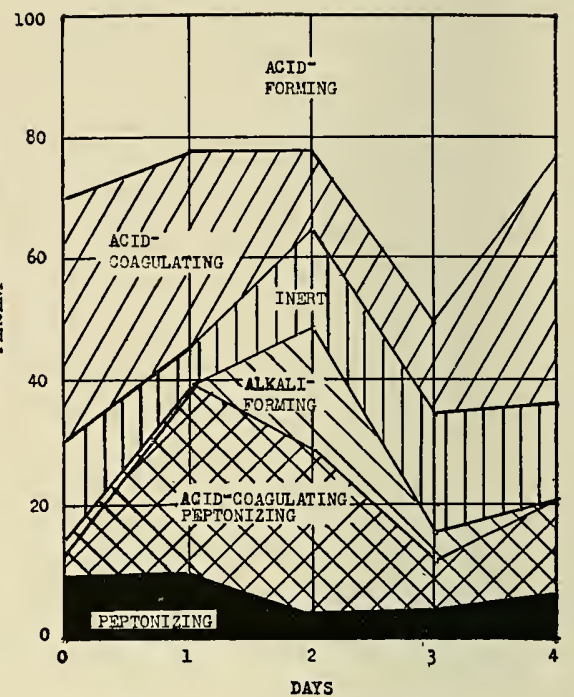

Fig. 5-Daily changes of the proportions of the physiologic types of bacteria in high-grade milk on storage for four days at $41^{\circ}$ to $46^{\circ} \mathrm{F}$.

* Acid-coagulating-peptonizing.

on the third day, when no significant bacterial count increase had occurred.

RAW MILK

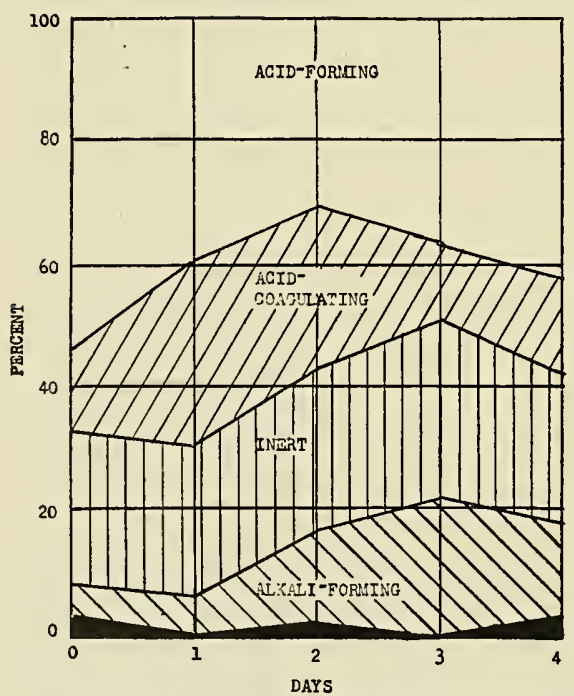

MILK PASTEURIZED AND BOTTLED

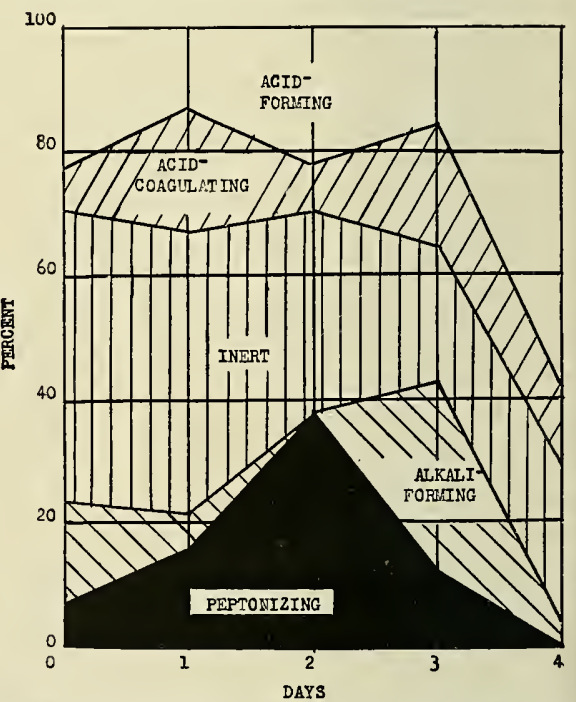

FIG. 6-Daily changes of the proportions of the physiologic types of bacteria in high-grade milk on storage for four days at $36^{\circ}$ to $40^{\circ} \mathrm{F}$. 
The results of the study of changes of physiologic types on storage are shown by cumulative graphs in Figures 4 to 6 . The comparisons of particular interest are between raw and bottled pasteurized milks, and between storage temperatures. Throughout the data a tendency is evident for the percentages of peptonizing organisms in the pasteurized-bottled milk to exceed those of the raw milks. The percentages of these organisms decrease on the third and fourth days, however. At $53^{\circ}-56^{\circ} \mathrm{F}$. the alkali-forming bacteria in the pasteurized bottled milks overgrew all other types, whereas in the raw milks they increased in percentage during the first day, remained constant for two days, and decreased during the fourth, the largest percentage increase being made by the acid-forming group. Neither raw nor pasteurized-bottled milks showed marked changes of percentage of acid-coagulating organisms on storage at any of the temperatures used, whereas the percentages of acid-forming bacteria were more variable, though exhibiting no definite, general trend.

\section{SUMMARY}

Pasteurization of low-count milk, under the conditions obtaining in these experiments, changes the bacterial flora so that on subsequent storage acid develops slowly and coagulation occurs at low acidities, apparently because of the production of a rennin-like enzyme by the bacteria.

The methods used in these experiments show no tendency for peptonizing bacteria to overgrow other types in raw or pasteurizedbottled milks held for four days at temperatures ranging from $36^{\circ}$ - $56^{\circ} \mathrm{F}$. $\left(2.2^{\circ}-13.2^{\circ} \mathrm{C}\right.$. $)$.

There was a decided tendency under the conditions obtaining in these experiments for the pasteurized-bottled milks to develop a "cappy" flavor after two days' storage at temperatures ranging from $36^{\circ}-56^{\circ} \mathrm{F}$.

\section{LITERATURE CITED}

(1) ANONYMOUS.

1927. STANDARD Methods of Milk aNalysis. Ed. 5, American Public Health Association, New York.

(2) AYres, S. H., AND JoHnson, W. T.

1913. THE BACTERIOLOGY OF COMMERCIALLY PASTEURIZED AND RAW MARKET MILK. U. S. D. A. Bur. Animal Ind. Bul. 161

$(3)$

1913. THE BACTERIOLOGY OF COMMERCIALLY PASTEURIZED AND RAW MARKET MILK. U. S. D. A. Bur. Animal Ind. Bul. 161.

(4) 1915. THE ABILITy of COLON BACILli TO SURVIVE PASTEURtzation. Jour. Agr. Res. 3:401.

( 5 ) $\longrightarrow$ Rupp, P., AND JoHnson, W. T.

1919. A STUDY OF THE ALKALI-FORMING BACTERIA FOUND IN MILK. U. S. D. A. Bur. Animal Ind. Bul. 782. 
(6) Beavans, E. A.

1930. THE Escherichia-Aerobacter GROUP AS AN INDEX TO PROPER PASTEURIZATION. Jour. Dairy Sei. 13:94.

( 7 ) Black, L. A., Prouty, C. C., and Graham, R. A.

1932. THE EFFECT OF PASTEURIZATION ON THE BACTERIAL FLORA OF LOWCOUNT MILK. Jour. Dairy Sc. 15:99.

( 8 ) HaMmer, B. W.

1928. Dairy bacteriology. John Wiley and Sons, Ine., New York.

(9) - AND Trout, G. M.

1928. A STUDY OF THE YELLOW COCCI WHICH SURVIVE PASTEURIZATION. Jour. Dairy Sci. 11:18.

(10) Harding, H. A., Ward, A. R., and Harding, H. J.

1929. THE BACTERIAL FLORA OF PASTEURIZED MILK. Jour. Bact. 17:35.

(11) Heinemann, R. G., and Glenn, T. H.

1909. EXPERIMENTS ON THE GERMICIDAL ACTION OF COW'S MILK. JOur. Inf. Dis. $5: 524$.

(12) HuCKER, G. J.

1928. STUDIES OF THE COCCACAE: IV. A STUDY OF TIHE COCCI RESISTing Pasteurization temperatures. N. Y. Agr. Exp. Sta. Bul. 134.

(13) Husong, R. V., ANd Hammer, B. W.

1931. THE PASTEURIZATION EFFICIENCIES SECURED WITH MILK FROM indVIDUAL farms. Iowa Agr. Exp. Sta. Bul. 286.

(14) Maze, P.

1907. Pasteurization du Lait destin a la consommation. L'Ind. Lait $32: 121$.

(15) NORTH, C. E.

1918. GROWTH OF BACTERIA AT DIFFERENT TEMPERATURES. Farmers' Clean Milk Book, p. 67. John Wiley \& Sons, Ine., New York.

(16) PRicketT, P. A.

1929. THERMOPHILIC AND THERMODURIC MICROORGANISMS WITH SPECIAL REFERENCE TO SPECIES ISOLATED FROM MILKS: V. THERMOPHILIC SPORE-Formers associated With MilK. N. Y. Agr. Exp. Sta. Tech. Bul. 147.

(17) RoBertson, A. H.

1927. THERMOPHILIC AND THERMODURIC MICROORGANISMS WITH SPECIAL REFERENCE TO SPECIES ISOLATED FROM MILKS: III. DESCRIPTION OF THE NON-SPORE-FORMING THERMODURIC ORGANISMS ISOLATED. N. Y. Agr. Exp. Sta. Tech. Bul. 131.

(18)

(20) ROGERS, L. A.

1927. THERAIOPHILIC AND THERMODURIC MICROORGANISMS WITH SPECLAI REFERENCE TO THE SPECIES ISOLATED FROM MILK: II. THE THERMAL RESISTANCE OF MiCROORganisms. Vermont Agr. Exp. Sta. Bul. 274.

1927. THERMOPHILIC AND THERMODURIC MICROORGANISMS WITH SPECIAL REFERENCE TO THE SPECIES ISOLATED FROM MILK: IV. EFFECT OF AGE OF CULTURE ON THE HEAT RESISTANCE OF NON-SPOREFORMING BACTERIA. Vermont Agr. Exp. Sta. Bul. 275.

1905. THE BACTERIA OF PASTEURIZED AND UNPASTEURIZED MILK UNDER LABORATORY CONDitions. U. S. D. A. Bur. Animal Ind. Bul. 73.

(21) Ross, H. E.

1927. The Care AND handling of Milk, p. 152. Orange Judd Publishing Co., New York.

(22) Sherman, J. M., Stark, C. N., and Stark, Pauline.

1929. AN UNAPPRECIATED BUT IMPORTANT FACTOR IN THE PASTEURIZATION OF MILK. Jour. Dairy Sci. $12: 385$.

(23) Tanner, F. W., And Harding, H. G.

1926. THERMOPHILIC BACTERIA IN MILK. Jour. Bact. 11:96.

(24) - AND Windsor, Mary F.

1929. THE ABILITY OF Escherichia coli AND Seratia marcescens TO sURVIVE $62.8^{\circ} \mathrm{C}$. FOR 30 MiNutes IN MILK. Jour. Dairy Sci. 12:202. 

